\title{
An Analysis on Halal Tourism Potential: An Overview of the Educational Aspects and Number of Tourist Visits
}

\author{
Martaleni ${ }^{1 *}$, Adya Hermawati ${ }^{2}$, Sri Budhi Pudji Handhajani ${ }^{3}$, Ni Nyoman Kerti Yasa ${ }^{4}$ \\ ${ }^{1}$ Department of Management, University of Gajayana, Malang, Indonesia \\ ${ }^{2}$ Master Program of Management, University of Widyagama Malang, Indonesia \\ ${ }^{3}$ Department of Information System, University of Gajayana, Malang, Indonesia \\ ${ }^{4}$ Faculty of Economic and Business, University of Udayana, Bali, Indonesia
}

\begin{abstract}
The phenomenon of the Islamic economy recently is a principal part of the global economy. The brands and services with halal/sharia concept in many products have become increasingly trending in the global economy, including in the tourism industry. Opportunities for the development of halal tourism are widely open as the rapidly growing Muslim population in the world. This study aims to analyse the potential of halal tourism from the educational aspect and the number of tourist visits to Bromo Tengger National Park. Primary data were collected through distributing questionnaires to Muslim tourists, in which the judgment sampling method was used for the selection of respondents. The number of respondents who filled out the questionnaire was 250 people. Furthermore, the data were analyzed using the exploratory multivariate method. Tourist education and the number of tourist visits to Bromo Tengger act as aspects that can influence tourist perceptions in providing an assessment of the potential of halal tourist destinations. The results showed that the tourists gave a pretty good perception for every aspect of measuring halal tourist destination. Based on the research results, it can be concluded that the Bromo Tengger destination has the potential as a halal tourist destination.
\end{abstract}

Keywords: halal tourism, potential, tourists.

\section{INTRODUCTION}

As the Islamic economic phenomenon is an important part of the global economy today, halal/sharia-based business has been developing and has become trending in the global economy [1-4]. Halal in Arabic can be interpreted as allowed. At present, the concept of halal has been developed into various products termed sharia. The products include banking transactions, Hotel/lodging, insurance, and tourism, thus such terms as Sharia Bank, Sharia Hotel/Lodging, Sharia Insurance, and Sharia Tourism emerge.

Islamic tourism is a complex matter, it is dependent on the type of tour, location, purpose, and activity offered. Halal tourism has gained popularity and has become a new phenomenon in the tourism industry in countries around the world, if not becoming a new lifestyle trend $[2,5]$. Therefore, many countries begin to introduce halal concept tourism products, even in countries where Muslims are not the major population [6]. Some of these countries include Japan, Australia, Thailand, New Zealand, India, and so forth $[6,7]$.

\footnotetext{
* Correspondence address:

Martaleni

Email : martaleni@unigamalang.ac.id

Address : Jl. Mertojoyo Blk. L, Merjosari, Malang, 65144
}

There are opportunities for the development of halal tourism, considering the rapid growth of the Muslim population in the world. The rapid population growth in a country can be an opportunity to expand the targeted market of a product or service [8]. In 2030, the Muslim population is predicted to grow by $26 \%$ of the world's population Global Muslim Travel Index, hereinafter abbreviated as GMTI [9]. The Muslim travel sector growth will continue to be one of the fastest-growing sectors in the world. It is estimated to grow up to 150 million migrants by 2020 with an expenditure of $\$ 250$ billion. Table 1 is the list of the 20 major countries with popular Muslim tourist destinations. Ten countries are members of the Organization of Islamic Cooperation $(O I C)$, and the other ten is not affiliated with OIC or referred to as Non-OIC countries.

Table 1. Twenty-Major Muslim Tourist Destination Countries

\begin{tabular}{clcll}
\hline Rank & $\begin{array}{c}\text { OIC } \\
\text { Destinations }\end{array}$ & Score & $\begin{array}{c}\text { Non-OIC } \\
\text { Destinations }\end{array}$ & Rank \\
\hline 1 & Malaysia & 83.8 & Singapore & 65.1 \\
2 & Turkey & 73.8 & Thailand & 59.2 \\
3 & UAE & 72.1 & United Kingdom & 55.0 \\
4 & Saudi Arabia & 71.3 & South Africa & 51.1 \\
5 & Qatar & 68.2 & France & 48.2 \\
6 & Indonesia & 67.5 & Belgium & 47.5 \\
7 & Oman & 66.7 & Hong Kong & 47.5 \\
8 & Jordan & 66.4 & The USA & 47.3 \\
9 & Morocco & 64.4 & Spain & 46.5 \\
10 & Brunei & 64.5 & Taiwanese & 46.1 \\
\hline
\end{tabular}

Source: Global Muslim Travel Index/GMTI, 2015. 
Based on Table 1, Malaysia as a member of the OIC is the most sought after by Muslim tourists with the highest score (83.8) among nine others. Meanwhile, Indonesia, with a score of 67.5, is in the top 6, below Turkey, UAE, Saudi Arabia, and Qatar. As for the Non-OIC countries, Singapore is the most highly demanded by world Muslim women reaching the score of 65.1, followed by Thailand, the UK, South Africa, and France, consecutively. With the increasing number of Muslim community visits, it is clear that the demand for halal products will also increase. It shows that Muslims contribute significantly to the world of tourism, or in other words, the Muslim market is a huge potential for the halal tourism market. Therefore, the need to develop halal tourism is very high. Which, however, is not proportional to the effort. Thus, the presentation and description of halal tourism are crucial [10].

Indonesia has the largest Muslim majority population in the world that already has halalcertified businesses, including 37 hotels, 300 restaurants, 27 transportation businesses, and 13 tourist destinations classified as Muslim-friendly. Thus, it can be seen that Indonesia has a good position as a potential market in the halal tourism industry [11]. In a study on the development of tourist destinations in Indonesia, Bromo Tengger Semeru National Park (East Java) is one of the ten tourism destinations in Indonesia that is prioritized for development in 2016-2019. It is one of the tourist destinations that has a variety of very beautiful tourist objects with easy access to reach and has been able to increase the interest of tourist visits both foreign and domestic tourists [12].

It is targeted to increase tourist visits from Malaysia, Singapore, China, Japan, European Countries and the Middle East. Most local tourists come from cities in Java and Bali Islands [13]. From the tourism visit target that previously mentioned, there are two mostly-Muslimpopulated countries: Malaysia and the Middle East. Thus the developing Bromo Tengger National Park as one of the halal tourism destinations is a necessity. Meanwhile, the tourism business actors in Bromo Tengger are the Tengger tribe. They live around Bromo Tengger, and the majority are Hindus. It is an interesting challenge as well as a new opportunity to meet the needs of Muslim tourists. In general, Muslim tourists are very concerned about the halal aspects of the products they will use. Therefore, this study aims to analyze the potential for halal tourism in Bromo Tengger.

\section{Halal Tourism Review}

Currently, halal tourism has become a form of tourism that attracts many countries. In line with this, various studies and researches have been carried out continuously to obtain information that can be used as material to optimize strategies in promoting it. However, studies on halal tourism, including the promotion of halal tourism in Indonesia, are currently rare [14], including in Bromo Tengger Semeru.

Tourism is a basic concept that encompasses a variety of behaviors in social, economic, political, cultural, environmental, and so forth, which has an important role in the development of a country's economy $[15,16]$. The concept of tourism consists of a series of activities, services, and benefits, all of which give tourists a specific experience [Medic and Middleton, 1973 in 15]. The tourism industry generally has grown into a vital global activity in various countries in the world. It shows that today tourism sector is highly dynamic, always offering new business opportunities and challenges to continue to improve competitiveness through creative innovation in the tourism industry.

Halal tourism is one of the new tourism phenomena in the halal industry $[2,6,17,18]$ who value the principles of upholding Islamic culture and values $[5,15]$ and is often referred to as Islamic tourism or Halal Tourism or Sharia tourism. Some countries use such terms as Islamic tourism, halal tourism, halal travel, or Muslim-friendly destinations [19]. Halal is defined as justified, while haram is prohibited. In Indonesia, halal tourism has long been developing in the form of pilgrimages. Along with global developments, this type of tourism experiences a metamorphosis that requires modern changes from attractions, hotels, to marketing. With a phenomenological approach, it is suggested that halal tourism has become part of the national tourism industry to place Indonesia as the future centre of halal tourism in the world [3].

Changes require an in-depth study of tourist behaviour. For example, gender-based behaviour found differences between male and female tourists in the selection of tourist attributes when determining the tourist destinations to visit [1]. Female tourists are more focused on privacy issues in the crowded public space, while men are more on religious facilities and other halal facilities. Furthermore, tourist motivation has a significant effect on overall tourist satisfaction $[1,20]$. But there 
is no significant relationship between motivation and satisfaction with religious moderation.

The rapid development of the Muslim population today offers both an opportunity and a challenge for various industries whose target market is the Muslim segment. There is an increasing likelihood of Muslim counterparts to favor Muslim-friendly tourism destinations regardless of whether the destination is majorly Muslim populated or not. Developing the halal tourism industry is significantly needed to encourage traveling and visiting the destinations. Factors encouraging to travel and visit can play an important role in determining their attitude towards the desired destination. Attitude is an important factor in influencing consumer interest in buying halal products. People with a high positive attitude likely have a great interest in buying halal products [21].

Bozorgaghideh and Beegam [22], in their study of Halal tourism in Kerala, explained that Islam in Kerala is not a rooted religion, and since the Muslim population has grown rapidly in the world, they target Muslim tourists for this reason. Thus, it is a must, as one of the attraction factors, for them to provide Islamic facilities such as mosques $[5,23]$. India is starting to be aware of this opportunity by making sure that its nature tourism destinations are Muslim-friendly and guarantee their comfort in worship while away from home.

From the findings of these studies, it is expected that the rapid growth of the Muslim population has provided opportunities for new market segments (Muslim markets) for countries in the world that have tourist destinations. In traveling, halal attributes have become the concern of Muslim tourists in choosing tourist destinations, so that the availability of those facilities is expected to lead to tourist satisfaction.

\section{MATERIAL AND METHOD}

This study is descriptive research with a quantitative approach. Malhotra [24] stated that quantitative research uses data in the form of numbers and statistical analysis. The type of data in this study is qualitative data sourced from primary data. Primary data is obtained by distributing a list of questions to respondents.

The populations in this research are all domestic Muslim tourists who visit Bromo Tengger National Park. Since the total population in the research was spread and unknown, the samples were collected under Sekaran suggests that descriptive research must have at least 30 up to 500 samples at most [25]. Similarly, Hair et al. [26] stated that the appropriate sample size is 100 200. Thus, in this study, the sample used is 250 . We used judgment sampling techniques [24] when determining the sample in this research.

Respondents to be sampled were determined by the following criteria: (1) aged $\geq 17$ years, (2) Muslim, (3) originating from areas outside Bromo Tengger National Park. There are four measurement variables: (1) tourism attractions, (2) Hotel and restaurants, (3) travel agents, and (4) tour guides. Indicator of tourism attractions variables as follow, performances following Islamic law, a clean environment, providing mosques with sufficient water for purification, and providing halal food and drinks in a tourist environment. Indicator of hotels and restaurants variable as follows: provides a place for ablution, has directions for qibla, cleanliness. Indicator of travel agency variable: it provides a list of information on halal accommodation and a list of halal food and beverages. Indicator of guide tours variable: carry out Islamic values, have good character, be communicative and dress according to Islamic law.

The assessment of each indicator used an ordinal scale in the form of a Likert scale with the following intervals: 5 for strongly agree to 1 for strongly disagree. Descriptive statistical analysis techniques were used to describe the characteristics of each respondent in the study. Furthermore, to answer the research objectives, descriptive statistical analysis techniques and explorative multivariate biplot analysis using XLSTAT software are used.

\section{RESULT AND DISCUSSION \\ Profile of Respondents}

From the 375 questionnaires distributed, 250 were filled by respondents and thus were used for further processing. The respondent's identity includes the number of visits and the level of education. From the respondent's distribution number that visited Bromo Tengger National Park, it reveals that $44 \%$ of respondents only visited Bromo Tengger once, $31 \%$ twice, $11 \%$ three times, and $14 \%$ four times. Most respondents have a Bachelor's degree (48\%), 32\% are high school leavers, $12 \%$ are Diploma graduates, and $8 \%$ are Postgraduates. It gave a general description of the tourists visiting Bromo Tengger National Park, who are mostly Bachelor graduates and High School leavers.

Figure 1 shows that tourists who visit Bromo Tengger for the first time give a higher perception to 
the hotel and restaurant aspects of halal tourism, followed by travel bureaus, tour guides, and attractions respectively. Those visiting for the second time give a better assessment for the guides as an aspect of halal tourism. Those who have been there for the third time are more concerned with the attraction. For those visiting four times, the attractions, hotels, and restaurants are what matters the most. It can be interpreted that first-time visitors have different priorities to various aspects of halal tourism. The more frequent a tourist visiting the place, the more they focus on the aspect of attraction, yet on the fourth visit, they don't favor the aspect. Likewise, the hotel and restaurant tend to be the favored aspects as more frequent visits, except for the second visit where the tourists tend to give a lower value to hotels and restaurants. However, the tour guides still favored Bromo Tengger National Park as a challenging tourist spot located in the highlands and with a vast expanse of desert.

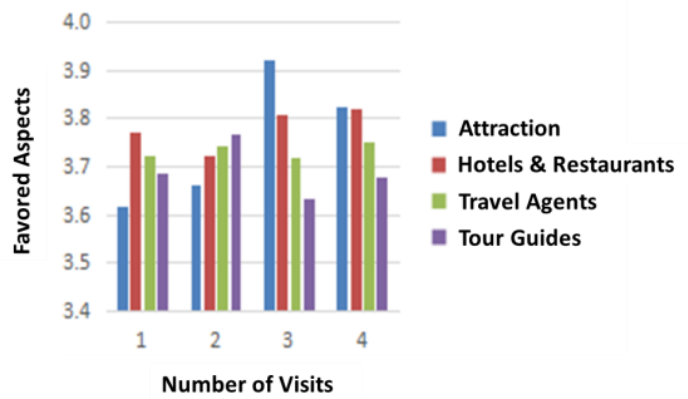

Figure 1. Description of the respondent's response based on Number of Visits (Source: Data processed, 2018)

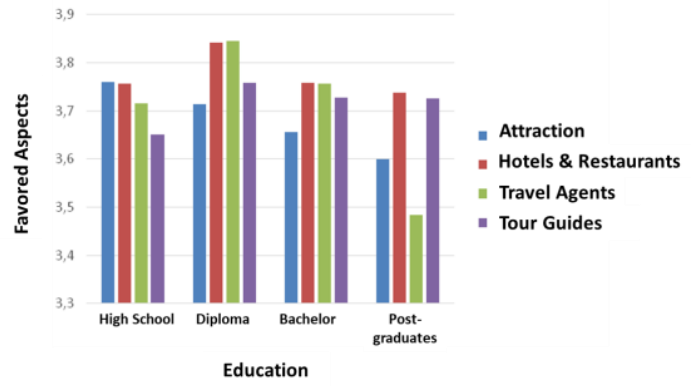

Figure 2. Description of respondent responses based on Education (Source: Data processed, 2018)

Figure 2 shows that high school-leaver tourists give the same priority to attractions and hotels and restaurants, followed by travel and tour guides as an aspect of halal tourism. For diploma graduate tourists, hotels, restaurants, and travel agents are relatively equally favored, followed by tour guides and attractions. While Bachelor graduate tourists also provide relatively similar assessments of hotels and restaurants, and travel agencies, followed by guides and attractions. Likewise, Postgraduate graduate tourists gave a similar assessment of attractions and guides, followed by attractions and travel agents considered relatively slightly lower. It can be interpreted that various aspects of halal tourism in Bromo Tengger National park are judged differently by tourists based on their level of education. However, travel agencies and attractions aspects need to get serious attention on the likelihood that the higher the level of education of the tourists, the lower the value of the halal tourism aspect is given.

\section{Biplot Analysis Results}

Before we use the Biplot Analysis, an eigenvalue was calculated to see the suitability of the model. The biplot analysis is shown below.

\section{Biplots Based on Tourist Education Level}

Scree plots depicted based on eigenvalues can be used to see the suitability of the model. The conformity value measure illustrated in the twodimensional figure is $96.01 \%$ for the first two components and the second factor (Fig. 3). This value is quite high, so the biplot results obtained are highly representative and can be further interpreted.



Figure 3. Scree Plots and Eigen Value Objects Based on Education (Source: Data processed, 2018)

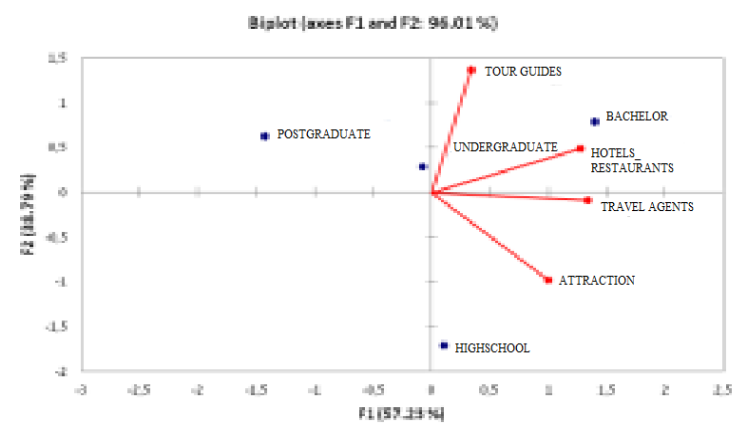

Figure 4. Object Biplot Based on Education (Source: Data processed, 2018) 
Based on Figure 4, the four variablesattraction, tour guides, travel agents, and hotels and restaurants-have a positive correlation, where tourists are concerned with all four aspects. The travel agents, and hotels and restaurants are more closely related than the attraction of tourists in terms of the position of the vector angle. The Tour Guide variable has the same relative diversity with a relatively short vector length, judging from the length of the vector formed. It indicates the response to the importance of the four aspects: attractions, guides, travel agents, and hotels and restaurants tend to be the same or stable among tourists based on their educational background.

The biplots formed do not indicate a grouping of tourists based on their education, if not tend to spread. It indicates that tourists with their different educational backgrounds have different responses in viewing the importance of halal tourism in terms of attractions, guides, travel agents, and hotels and restaurants. Bachelorgraduate tourists tend to prioritize aspects of tour guides. Diploma-graduate respondents are more concerned with aspects of hotels and restaurants. Respondents with a high school and postgraduate education were less likely to prioritize halal tourism in all aspects.

\section{Biplot Based on Number of Visits}

Scree plots described based on eigenvalues can be used to see the suitability of the model. The value of conformity size that can be illustrated in the two-dimensional drawings is equal to $92.8 \%$ for the two first and second factor components (Fig. 5). This value is quite high, so the biplot results obtained are highly representative and can be further interpreted.

\begin{tabular}{|c|c|c|c|}
\hline \multicolumn{4}{|c|}{ Eigenvalues } \\
\hline & F1 & F2 & F3 \\
\hline Eigenvalue & 2.652 & 1.062 & 0.286 \\
\hline Variability (\%) & 66.298 & 26.545 & 7.156 \\
\hline Cumulative (\%) & 66.298 & 92.844 & 100.000 \\
\hline
\end{tabular}

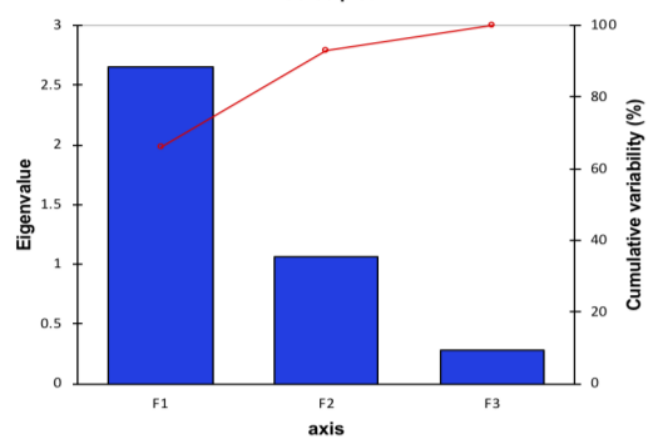

Figure 5. Scree Plot and Eigenvalue of Object Based on Number of Visits (Source: Data processed, 2018)
Figure 6 presents the information about the object number of visits by respondents, the variable attraction, and hotels and restaurants have a strong and positive correlation (almost perfect seeing from the almost-colliding vectors in the chart). It can be concluded that tourists, who have been grouped based on the number of visits to Bromo, judge that the importance of halal tourism in the attraction aspect is in line with the importance of the hotels and restaurant aspects.

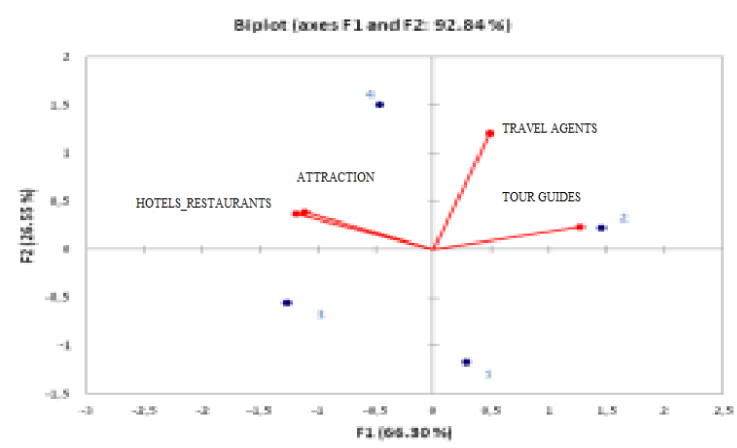

Figure 6. Object Biplot Based on Number of Visits (Source: Data processed, 2018)

On the other hand, the relationship between the variable of the hotels and restaurant with attraction is the opposite of the travel agents and tour guides variables shown by the opposing vectors. But the relationship between travel agents' variable and tour guide variable is mutually positive. It means that if the travel agents' response is considered important, then the tour guide is also important.

The tour guide variable has the highest diversity, followed by hotels and restaurants, travel agents, and attractions, judging from the length of the vector form. High diversity indicates that responses to the importance of tour guides are relatively more diverse among respondents, while responses to attractions tend to be the same or stable. Judging from the number of visits, tourists who visited Bromo for the first time and those who visited Bromo four times less likely to prioritize halal tourism in all its aspects. Those visiting twice are more concerned with the tour guides. Whereas respondents who have visited Bromo for the third times tended to favor the importance of the attraction, and hotels and restaurants aspects. It can explain that the number of tourist visits provides a different view of the aspect of halal tourism.

\section{DISCUSSION}

If grouped based on the tourists' education level, it does not indicate tourist grouping based on their education in seeing aspects of halal tourism. It can be stated that there are different views from tourists in looking at aspects of halal tourism. Tourists with a 
bachelor's degree tend to prioritize aspects of tour guides. Diploma-educated tourists prioritize the aspects of hotels and restaurants, tourists with high school and postgraduate education less likely to prioritize halal tourism in all aspects. Judging from the number of tourist visits, it doesn't seem that the first- and fourth-time tourists who visit Bromo Tengger National Park tend to prioritize all aspects of halal tourism. Those visiting for the second time prioritize the aspects of tour guides. Meanwhile, those visiting for the third time tend to favor the attractions and hotels and restaurants aspects.

Based on these findings, Bromo Tengger National Park is following predetermined criteria. Thus, it makes Bromo Tengger National Park a Muslim-friendly or a halal tourism destination. The halal tourism industry is an emerging phenomenon from the growth of the halal industry [6] or a new business opportunity that meets the unique needs of Muslim tourists when they are far away from home [27]. Providing what Muslim travelers need of halal facilities will meet the satisfaction of the tourist $[28,29,30,31]$. However, it all depends on the management or related agencies to expand the market share by targeting the Muslim segment of tourists who tend to favor Muslim-friendly tourist destinations. Managerial skills are needed in adjusting to ethnic or religious attributes [8,32].

Tourism product development, innovation, transformation, and marketing have an important role in advancing tourist destinations with an Islamic approach. The fundamental of halal tourism is the understanding of the meaning of halal in all aspects of tourism activities, including hotels, transportation facilities, food and beverage facilities, the financial system, to the facilities and service providers themselves $[4,33,34]$. It is necessary to meet the expectations of Muslim tourists. It means not only to provide the desired experience to tourists but also protecting the values and quality of life that exists in tourist destinations [15].

The results of this research are the basis for further and in-depth study of Bromo Tengger tourist destination policymakers, especially the Central and Regional Governments, in developing the potential of Bromo Tengger as a Halal tourist destination. Halal tourism is considered crucial for national income and the development of local communities, so it needs to be managed wisely [35].

\section{CONCLUSION}

Based on the results of research and discussion, it can be concluded that tourists have relatively good perceptions for every aspect of the halal tourist destination measures of Bromo Tengger National Park. Based on the level of education, tourists provide different views on the importance of the aspect of halal tourism in Bromo Tengger. Bacheloreducated tourists tend to prioritize aspects of tour guides. Diploma-educated tourists attach more importance to the aspects of hotels and restaurants. High school and postgraduate educated tourists were less likely to put importance on halal tourism in all aspects.

Likewise, when viewed from the number of visits, it can be explained that the number of tourist visits to the Bromo Tengger National Park provides a different view of the aspect of halal tourism. The tourists who visit Bromo Tengger for the first time or for the fourth time do not prioritize too much on the halal tourism concept in all aspects. Tourists who visit Bromo Tengger for the second time are more concerned with aspects of tour guides, whereas tourists who have visited Bromo for the third time tend to pay attention to the importance of the attraction and hotels and restaurants aspects. So, it can be implied that Bromo Tengger National Park has the potential to be a halal tourist destination. However, in-depth and thorough study are needed to achieve maximum offer.

\section{REFERENCES}

[1] Battour, M, M. N. Ismail, and M. Battor. 2010. The impact of destination attributes on Muslim tourist's choice. International Journal of Tourism Research 13(6), 527-540. DOI: 10.1002/jtr.824.

[2] Chandra, G., Ramesh. 2014. Halal tourism; A new goldmine for tourism. International Journal of Business 4(6), 45-62.

[3] Jaelani, A. 2017. Halal tourism industry in Indonesia: potential and prospects. International Review of management and Marketing 7(3), 25-34.

[4] Martaleni. 2019. Halal tourism. CV. IRDH. ISBN: 978-602-07026-72-4.

[5] Kessler, K. 2015. Conseptualizing mosque tourism: a central fiture of Islamic and religious tourism. International Journal of Religious Tourism 3(2), 11-32.

[6] Samori, Z., N. Z. Salleh, and M. M. Khalid, 2016. Current trends on halal tourism: case on selected Asian country. Tourists Management Perspective 19, 131-136. 
[7] Chookaew, S., O. Chanin, J. Charatarawat, P. Sriprasert, and S. Nimpaya. 2015. Increasing halal tourism potential at Andaman Gulf in Thailand for Muslim country. Journal of Economic, Business and Management 3(7), 739-741.

[8] Kotler, P., and K. L. Keller. 2014. Marketing management. Pearson Education, Inc. New Jersey.

[9] Global Muslim Travel Index (GMTI). 2016. Report MasterCard Crescent Rating Global Muslim Travel Index 2016. Available at: https://newsroom.mastercard.com/asiapacific/files/2016/03/Report-MasterCardCrescentRating-Global-Muslim-Travel-Index2016.

[10] Suherlan, A. 2015. Persepsi masyarakat Jakarta terhadap Islamic Tourism. The Journal of Tauhidinomics 1(1), 61-72.

[11] Purusottama, A., and G. D. H. Prestowo 2020. Halal tourism: its attractiveness to domestic tourists based on their religious perspectives. Journal of Indonesian Tourism and Development Studies 7(3), 146-155.

[12] Fanani, Z., and E. Pangestuti. 2017. Analisis keamanan dan kenyamanan objek wisata penanjakan. Jurnal Administrasi Bisnis (JAB) 49(2), 63-67.

[13] Ratman, D. R. 2016. Pengembangan destinasi pariwisata prioritas 2016-2019. Pesona Indonesia.

[14] Suradin, M. 2018. Halal tourism promotion in indonesia: an analysis on official destination websites. Journal of Indonesian Tourism and Development Studies 6(3), 143-148.

[15] Tajzadeh-Namin, A. A. 2013. Value creation in tourism: an Islamic approach. International Research Journal of Applied and Basic Sciences 4(0), 1252-1264.

[16] Martaleni. 2017. Pemasaran pariwisata Indonesia. International Research and Development for Human Beings (Research and Publishing). Malang.

[17] Fahim, S. T., and E. N. Dooty. 2014. Islamic tourism: in the perspective of Bangladesh. Global Journal of Management and Business Research 14(1), JEL Code: Z12.

[18] Bhuiyam, M. D. A. H., S. Chamhuri, S. M. Ismail, R. Islam, D. Ehsan. 2014. Potentials of Islamic tourism: a case study of Malaysia on East Coast Economic Region. Australian Journal of Basic and Applied Sciences 5(6), 1333-1340.
[19] Andriani, D. et al. 2016. Kajian Pengembangan Wisata Syariah. Ministry of Tourism, Republic of Indonesia.

[20] Martaleni. 2014. Pengaruh motivasi, kualitan layanan, dan kepuasan wisatawan terhadap image daerah tujuan wisata. EKUITAS Jurnal Ekonomi dan Keuangan 18(2), 201-218.

[21] Afendi, N. A., F. L. Azizan, and A. I. Darami. 2015. Determinants of halal purchase intention; case in Perlis. International Journal of Business and Social Research 4(5), 118-123.

[22] Bozorgaghideh, N. and S. R. Beegam. 2015. Halal tourism in Kerala. International Journal of Management 6, 42-48.

[23] Martaleni, 2019. Halal tourism potential: an investigation in Bromo Tengger Indonesia. Revista San Gregorio 34, 189-107.

[24] Malhotra., and K. Naresh. 2009. Riset pemasaran pendekatan terapan. PT Indeks, Indonesia.

[25] Sekaran, U. 2003. Research methods for business: a skill- building approach. John Wiley and Sons, Inc.

[26] Hair, J. F., B. Black, B. J. Babin, and R. E. Anderson. 2010. Multivariate data analysis, $7^{\text {th }}$ Ed. Pearson Education International.

[27] Pungniyom, P. P., N. Swangcheng. and T. Mahamud. 2017. Halal tourism strategy to promote sustainable culture tourism in Thailand. International conference on studies in Art, Social Science and Humanities, 194-198.

[28] Putit, et al. 2016. Liking halal friendly hotel attributes and customer satisfaction: the Islamic tourism sector. Journal of Emerging Economic and Islamic Research 4, 43-53.

[29] Preko, A., I. Mohammed, and A. AzizbekAllaberganov. 2020. Islamic tourism: travel motivations, satisfaction and word of mouth, Ghana. Journal of Islamic Marketing, 17590833. DOI 10.1108/JIMA-04-2019-008.

[30] Eid, R. 2015. Integrating Muslim customer perceived value, satisfaction, loyalty and retention in the tourism industry: an emprical study. International Journal of Tourism Research 17, 249-260.

[31] Rahman, M. K. 2014. Motivating factors of Islamic tourist's destination loyalty: an empirical investigation in Malaysia. Journal of Tourism and Hotel Management 2(1), 63-77.

[32] Mohamed, N., A. Farmaki, B. Taheri, H. Watt, H. Olya, M. Joseph, and M. J. Gannon. 2020. Stimulating satisfaction and loyalty: transformative behaviour and Muslim consumers. International Journal of 
Contemporary Hotel Management 32(9), 2903-2923.

[33] Hammuri, G., and I. Eseynel. 2017. The analysis of hoteliers attitude towards the establishment of Islamic hotel policies: North Cyprus. Saudi journal of homanities and Social Sciences, 124-131. DOI: $10.21276 /$ sjhss.

[34] Sanchez, A.V., and M. M. Moral. 2019. Halal tourism: literature review and experts' view. Journal of Islamic Marketing 11(3), 549-569.

[35] Rosyidi, M. I. 2018. The challenges of developing tourism events in Bromo Tengger Semeru National Park. Journal of Indonesian Tourism and Development Studies 6(3), 159-166. 